\title{
CADÁVERES DE CÃES PREPARADOS E EMBALADOS À VÁCUO VISANDO AO ENSINO DA CIRURGIA VETERINÁRIA - EFEITO NA BIOMECÂNICA DA PELE
}

\section{Isabela Del Ponti', Giovana Carvalho Vieira², Andréa Barros Piazzon de Souza Queiroz ${ }^{3}$, Fabrício Singaretti de Oliveira ${ }^{4}$}

\begin{abstract}
1,2,3,4,5,6Universidade Estadual Paulista (UNESP) “Júlio de Mesquita Filho" - Faculdade de Ciências Agrárias e Veterinárias - Câmpus de Jaboticabal
\end{abstract}

DOI: $10.47094 /$ ICONRES.2021/26

Introdução: Atualmente, vários são os métodos alternativos que buscam o bem-estar animal no ensino da cirurgia, os quais visam substituir o emprego de animais vivos. As peças anatômicas são fixadas e comparadas a tecidos frescos, buscando modelo alternativo para o treinamento cirúrgico. Objetivo: determinar a força máxima de ruptura da pele, e o deslocamento para a ruptura, em cadáveres de cães preparados, comparativamente a frescos, além da avaliação dos graduandos de Medicina Veterinária dos cadáveres preparados. Metodologia: Foram utilizados 8 cadáveres de cães, colhidos 3 fragmentos de pele a fresco cada (amostras-controle) para análise biomecânica imediata. Após, cada cadáver recebeu solução composta por $120 \mathrm{ml} / \mathrm{kg}$ de sal cura, contendo $200 \mathrm{~g} / \mathrm{L}$ de cloreto de sódio, $10 \mathrm{~g} / \mathrm{L}$ de nitrito de sódio, $10 \mathrm{~g} / \mathrm{L}$ de nitrato de sódio, álcool etílico puro com 5\% de glicerina em relação ao volume do álcool, na quantidade de $150 \mathrm{ml} / \mathrm{kg}$ de peso corporal, via artéria carótida comum e embalados à vácuo e mantidos refrigerados. Considerando-se "dia zero" a colheita das amostrascontrole, foram, também, realizadas análises biomecânicas 7 dias consecutivos. Ademais, 8 cadáveres foram preparados com a mesma técnica descrita e disponibilizados aos alunos, dando-lhes escores de 1 a 10 referentes a maleabilidade da pele e incisão/sutura para comparação entre preparados e frescos. Resultados: Observou-se que não houve diferença significativa entre os tratamentos de força máxima de ruptura, assim como na análise de deslocamento, exceto nos dias 2 e 6 de tratamento. Assim, o preparo químico manteve as características biomecânicas por até 7 dias sob refrigeração utilizando embalagem à vácuo. Os escores avaliados foram maiores que 7,95 (0-10) representando ótima qualidade do material preparado. Conclusões: A técnica de conservação com álcool etílico e sais de cura, associado as embalagens a vácuo, tem bom custo-benefício, sendo um método efetivo na conservação das características biomecânicas da pele para treinamento cirúrgico.

Palavras-chave: Anatomia. Cirurgia. Diérese.

Área Temática: Medicina Veterinária 